\title{
ОПТИМІЗАЦІЯ ЗАВАНТАЖЕННЯ ПТЛ ЕЛЕВАТОРІВ ЗЕРНОМ: ФОРМАЛІЗАЦІЯ ТА ПІДВИЩЕННЯ ЕФЕКТИВНОСТІ АЛГОРИТМУ КЕРУВАННЯ
}

\author{
С. Шестопалов ${ }^{1}$, В. Хобін ${ }^{2}$ \\ ${ }^{1} \mathrm{SE}$ Group International, Одеса \\ ${ }^{2}$ Одеська національна академія харчових технологій
}

Copyright (C) 2017 by author and the journal "Automation technological and business - processes". This work is licensed under the Creative Commons Attribution International License (CC BY). http://creativecommons.org/licenses/by/4.0/

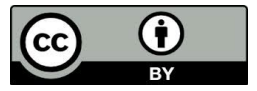

ONAFT

Open Access

Анотація: Практика показує, щзо у логістичному ланцюгу руху зерна від виробника до споживача задіяно, у середньому, три - чотири елеватори різного призначення та обсягу збереження. На елеваторах, у ході процесів приймання, підробітки та відвантаження, зерно переміщається потоково-транспортними лініями (ПТЛ). Таким чином, обсяги зерна, шуо перемішується ПТЛ елеваторів багаторазово, майже на порядок, перевершують обсяги його виробництва, які на Україні становлять десятки мільйонів тонн зерна щзорічно. Оскільки прощес переміщення зерна ПТЛ досить енергоємний та впливає на час простою під завантаженням/розвантаженням рухливого потягу, ияо транспортує зерно між елеваторами, то задача зниження часу та питомих енерговитрат на переміщення ПТЛ актуальна.

Разом з тим, функиія керування завантаженням ПТЛ, у т.ч. - ї̈ оптимізації за критерісм максимальної продуктивності та енергоеффективності, через складність їхніх властивостей як об'єкта керування (ОК), завжди зберігалася за людиною-оператором, як і відповідальність за результати неефективного керування. Ця складність визначається наявністю у ОК сукупності специфічних особливостей. До них відносяться: обмеження типу «аварійна ситуація» на режимні змінні прочесу транспортування; апріорна невідомість значень ичих меж; неможливість прямого виміру деяких важливих режимних змінних; досить істотні зміни динамічних властивостей ОК за каналами керування при зміні маршруту транспортування; а також, і ие принцииово важливо, те, щзо оптимальні режими роботи ПТЛ наближаються до аварійних. Забезпечити роботу ПТЛ у таких режимах можливо тільки при створенні ефективних систем автоматичного керування (САК), щуо враховують всі особливості ОК.

У статті розглядається повний математичний опис базового алгоритму керування САК зі структурою, щзо комутється, який забезпечує роботу ПТЛ із максимально досяжною продуктивністю та енергоефективністю при гарантованому запобіганні аварійних ситуацій (AC) та аварійних зупинок ПТЛ. Розглядається також один $з$ перспективних шляхів підвищення показників якості такої САК - застосування каскадної структури формування ї̈ керуючого впливу. Здійснюється порівняльний аналіз динаміки процесів керування в САК базової та каскадної структури.

Abstract: Practical experience reveals that in grain transferring logistics from manufacturer to consumer, in average, three - four elevators of different purposes and different holding volumes are involved. At elevators, while taking over, undermining and discharge, grain is being transferred by the means of thread-transport lines (TTLs). Thereby, grain volumes, which are being transferred by TTLs of the elevators, manifold, almost by far surpass the volumes of its production, which in Ukraine draw up to tens of millions of tons of grain per year. Since the process of grain transferring using TTLs is quite energy-consuming and influences the downtime under loading/discharge of mobile transport, which transfers the grain between elevators, the goal of time and specific energy-consumption for TTLs movements decrease is topical.

At the same time, function of the TTLs loading control, including its optimization using the criteria of maximum productivity and energy-efficiency, because of complexity of their specifics as control object (CO), were always reserved for operator, as well as liability for the results of inefficient control. This complexity is defined by CO having sum total of specific features. They include: limitations of the «emergency situation» type for the transferring process mode variables; a-priori uncertainty of this limitation values; impossibility of direct measurement of some important mode variables; quite substantial changes of control channels of $\mathrm{CO}$ dynamic features during change of transportation route; also, and this is principally important, that optimal operating modes of TTLs are very close to emergency ones. Ensuring the TTLs operation in these 
modes is possible only by designing effective systems of automatic control (SAC), which take into account all specifics of the $\mathrm{CO}$.

Full mathematical description of basic algorithm for automatic control of SAC with switched structure is described in this article. This algorithm ensures the TTLs operation with maximum obtainable efficiency and energy-efficiency with guaranteed prevention of emergency situations (ES) and emergency stops of TTLs. One of long-term ways of quality indicators increase in such system is shown as well. It is application of cascade structure for forming its control action. Comparative analysis of control processes dynamics in SAC of basic and cascade structures is carried out.

Ключові слова: перевантаження зерна, потоково-транспортні лінії, продуктивність, енергоефективність, безаварійність, оптимізація, система автоматичного керування, каскадна структура, що комутується.

Key words: grain transfer; thread-transport lines, productivity, energy-efficiency, fail-safe operation, optimization, algorithm, system of automatic control, commutating structure.

Сутність проблеми

Процеси перевантаження зерна реалізуються на зернових терміналах та елеваторах ПТЛ самих різних конфігурацій. У загальному випадку, ПТЛ складаються з декількох послідовно включених конвеєрів, включаючи в себе, як правило, норію. Час виконання операції перевантаження, повні та питомі енерговитрати на неї, за інших рівних умов, визначаються продуктивністю ПТЛ. Цілеспрямована зміна продуктивності ПТЛ здійснюється зміною ступеня відкриття регулюючої засувки i, отже, витрати зерна через неї із витратної ємності на перший, за напрямком руху продукту, конвеєр ПТЛ, тобто ії завантаженням зерном. Збільшення завантаження скорочує час перевантаження та витрати енергії на іiі реалізацію, що, врешті решт, підвищує економічну ефективність роботи підприємства. Максимально досяжна продуктивність ПТЛ відповідає їі максимально припустимому завантаженню, яке залежить від характеристик зерна, що перевантажується, особливостей конфігурації ПТЛ, конструкції та характеристик іiі конвеєрів, і, насамперед, норії.

Конструкція норій така, що перевищення іiі припустимого завантаження призводить до виникнення процесу переповнення їхніх робочих обсягів (башмака, труби висхідного потоку) зерном, який призводить до стану норії, що називають «завалом» або «підпором» зерна. Докладно динаміку розвитку підпору розглянуто в [1].

Виникнення підпору означає виникнення АС, коли подальший процес перевантаження зерна ПТЛ стає неможливий через загрозу переростання АС в аварію. Її основні наслідки: а) утворення багатотонних завалів зерна в місці його перевантаження 3 конвеєра в башмак норії; б) заклинювання стрічки норії зерном, ії прослизання на приводному барабані, перегрівання від тертя об приводний барабан, загоряння, обривання та обвалення в норійні труби, i, що імовірно, спровокує вибух повітряно-пилової суміші, що заповнює внутрішні обсяги норії. У штатних системах автоматизації такі погрози ліквідують спеціальні пристрої аварійного захисту, що відключають ПТЛ в аварійному режимі, тобто без їхнього розвантаження від зерна, що транспортується.

Постановка задачі

Для розробки алгоритмів керування (оптимізації) процесом завантаження ПТЛ важливо зауважити, що підпір зерна в башмаку норії виникає не миттєво, а в ході процесу нагромадження зерна, тобто через якийсь час після того, коли об'ємна продуктивність норії стала менше об'ємної продуктивності конвеєрів, що подають до неї зерно. Обмеження продуктивності норії обумовлено наявністю межі заповнення зерном ковшів норії, яке відповідає критичному (гранично припустимому) значенню об'ємної продуктивності норії [2]. Важливо, що це критичне значення апріорі невідоме, тому що на його конкретне значення впливають багато факторів, які можуть істотно змінюватися навіть у ході поточного процесу перевантаження. До таких факторів відносяться зміни характеристик: а) зерна, наприклад, його фракційного складу, коефіцієнта внутрішнього тертя і т.д.; б) технічного стану норії, наприклад, кількості частково або цілком обірваних ковшів, ступеня натягу та перекосу норійної стрічки. Останні характеристики впливають на амплітуду та частоту коливань ковшів i, отже, на фактичний ступінь їхнього заповнення зерном.

3 викладеного вище витікає, що максимум продуктивності ПТЛ досягається при їі критичному завантаженні, значення якого відповідає початку розвитку завалу в норії. У математичному сенсі розв'язання задачі пошуку максимуму в умовах обмежень $є$ задачею умовної оптимізації. Тут принципово важливо підкреслити, що значення обмежень у задачі оптимізації продуктивності ПТЛ апріорі невідоме.

Основу алгоритму оптимізації завантаження ПТЛ сформульовано в патенті на винахід України 95887, див. [3]. Його реалізація для ПТЛ, з конфігурацією, що істотно змінюється, та параметрами, вимагає його повної формалізації, тобто математичного опису i, насамперед, розробки структурної схеми САК для візуалізації її взаємозв'язків усіх іiї компонентів.

Математичний опис базової САК оптимізації завантаження ПТЛ

Структурну схему САК представлено на рис. 1. Вона відповідає блок-схемі САК, наведеній в [4], як приклад реалізації запропонованого способу керування, і яка описує САК на змістовному рівні. ОК в обох випадках $є$ процес перевантаження зерна ПТЛ. Його керовані змінні - відносний момент опору М на валу приводного електродвигуна (ПЕД) норії та подія $\mathrm{S}^{\text {дп }}$, що означає спрацьовування датчика підпору зерна в башмаку норії як етап розвитку АС, пов'язаної з перевищенням припустимого завантаження ПТЛ зерном. Його керуючі впливи - положення и 
регулюючої підсилосної засувки, через яку зерно подається в ПТЛ (на ії підсилосний транспортер) та швидкість и цього підсилосного транспортеру.

Структурна схема САК, у порівнянні з блок-схемою, описує ii на формальному рівні. При цьому визуалізуються зв'язки між математичним описом іiі елементів, додатково відображуються деякі важливі для реалізації особливості алгоритму керування - ті, які було неможливо, без втрати зв'язності викладу, проявити при його змістовному опису. До них відносяться необхідність обліку у настройювальних параметрах динамічних ланок моделі ОК та алгоритму керування від: а) часу транспортування зерна конвеєрами від точки завантаження до башмака норії, яке залежить від розташування силосу (його порядкового номеру $\mathrm{N}_{\mathrm{C}}$ на технологічній схемі); б) властивостей виду зерна, що транспортується, які визначають його продуктивність при витіканні через підсилосну засувку, критичний ступінь заповнення ковшів норії, значення відповідного навантаження на ПЕД (ці властивості будуть зберігатися в базі даних та будуть пов'язані з номером рядка, що відповідає номеру $\mathrm{N}_{\text {пр }}$, який привласнено виду зерна). Неконтрольовані варіації характеристик зерна (всередині одного типу) за п. «б», технічний стан норії та інші фактори формально об'єднано у вектор неконтрольованих збурень $\overrightarrow{\mathrm{F}}_{\mathrm{Hв}}$.

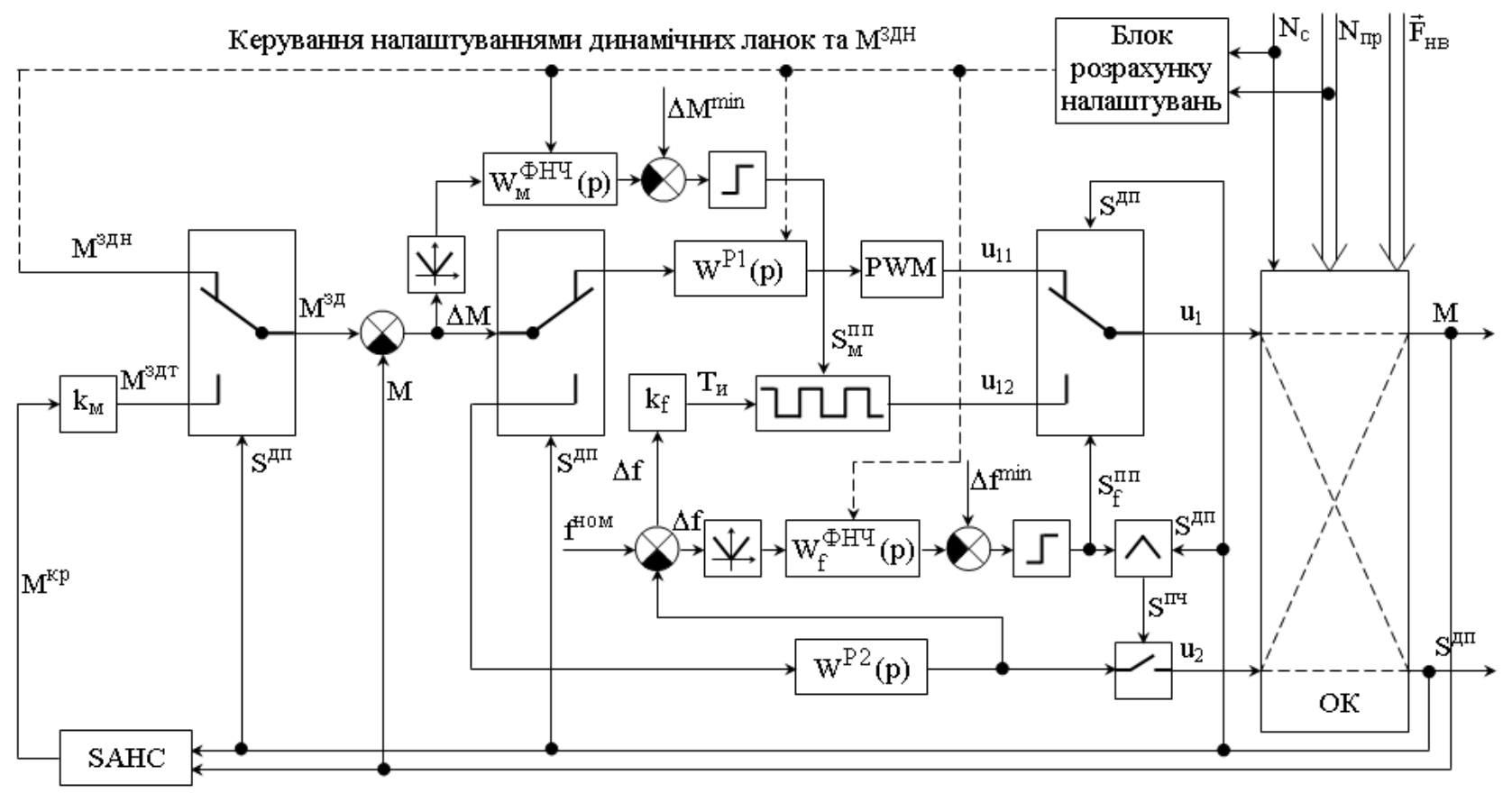

Рис. 1 - Структурна схема САК зі структурою, що комутується, завантаженням ПТЛ

Алгоритм керування, сформульований у [4] у змістовній формі, у математичній формі може бути представлений системою рівнянь:

$$
\mathrm{u}_{1}(\mathrm{t})=\left\{\begin{array}{l}
\mathrm{u}_{11}(\mathrm{t}), \text { при } \mathrm{S}^{\text {дп }}=0 \wedge \mathrm{S}_{\mathrm{f}}^{\text {пा }}=0 \\
\mathrm{u}_{12}(\mathrm{t}), \text { при } \mathrm{S}_{\mathrm{m}}^{\text {пा }}=1 \wedge \mathrm{S}_{\mathrm{f}}^{\Pi \Pi}=1
\end{array},\right.
$$

де $\mathrm{u}_{1}(\mathrm{t})$ - імпульсний керуючий вплив, що подається на виконавчий механізм із постійною швидкістю переміщення регулюючого органу, який спрощено можна описати динамічною ланкою 3 передавальною функцією $\mathrm{W}^{\text {им }}(\mathrm{P})=$ $1 / \mathrm{T}_{\text {имр }}$

«^» и « $\vee-$ символи логічних функцій, відповідно, «ТА» та «АБО»;

$$
\mathrm{u}_{11}(\mathrm{t})=\left\{\begin{array}{l}
\text { PWM }\left(\mathrm{W}^{\mathrm{P} 1}(\mathrm{p}) \Delta \mathrm{M}(\mathrm{t})\right), \text { при } \mathrm{S}^{\text {дп }}=0 \\
0, \text { при } \mathrm{S}^{\text {дп }}=0 \wedge \mathrm{S}_{\mathrm{f}}^{\mathrm{\Pi \Pi}}=1 \\
0, \text { при } \mathrm{S}^{\text {дп }}=1
\end{array},\right.
$$

де PWM (pulse-width modulation) - символ широтно-імпульсної модуляції змінної;

$\mathrm{k}_{\mathrm{M}}$ - коефіцієнт зниження навантаження ПЕД щодо ії критичного значення;

$\mathrm{W}^{\mathrm{P} 1}(\mathrm{p})$ - передавальна функція (варіант) регулятора першого контуру стабілізації М;

$$
\Delta M(t)=M^{\text {зд }}(t)-M(t)=\left\{\begin{array}{l}
M^{\text {здн }}\left(N_{3}\right)-M(t), \text { при } t=0 \\
M^{\text {3дт }}(t)-M(t), \text { при } S^{\text {дп }}=1 \vee t>t \Rightarrow S^{\text {дп }}=1
\end{array},\right.
$$


де SAHC (sample and hold circuit) - символ функції «вибірка-збереження»;

$$
\mathrm{M}^{3 / \mathrm{T}}(\mathrm{t})=\mathrm{k}_{\mathrm{M}} \mathrm{M}^{\mathrm{kp}}(\mathrm{t}), \mathrm{M}^{\mathrm{kp}}(\mathrm{t})=\mathrm{SAHC}\left(\mathrm{M}\left(\mathrm{t} \Rightarrow \mathrm{S}^{\text {גाI }}=1\right)\right),
$$

$$
\mathrm{W}^{\mathrm{P} 1}(\mathrm{p})=\mathrm{T}_{\text {им }} \mathrm{p} \frac{\mathrm{W}_{1}^{\mathrm{Mu}}(\mathrm{p})}{1+\mathrm{W}_{1}^{\mathrm{\Pi 1}}(\mathrm{p}) \mathrm{W}^{\mathrm{\Pi \pi}}(\mathrm{p})},
$$

де $\mathrm{p} \equiv \mathrm{d} / \mathrm{dt}$ - оператор диференціювання;

Тим - час переміщення виконавчим механізмом підбункерної засувки між ії крайніми положеннями; $\mathrm{W}^{\text {Пи }}(\mathrm{p})$;

$\mathrm{W}^{\Pi К}(\mathrm{p})$ - передавальні функції ПІ-регулятора та коригувального зв'язку, що прогнозує власний рух в контурі регулювання на час запізнювання вперед (випереджувач Сміта, див. [5]);

$$
\begin{aligned}
& \mathrm{W}_{1}^{\text {ПИ }}(\mathrm{p})=\mathrm{k}_{\mathrm{p} 1}\left(1+1 / \mathrm{T}_{\text {из1 }} \mathrm{p}\right), \\
& \mathrm{W}^{\Pi \kappa}(\mathrm{p})=\left(1-\mathrm{e}^{-\tau_{\mathrm{u}_{1}-\mathrm{MO}}^{\mathrm{MO}}}\right) \mathrm{W}_{\mathrm{u}_{1}-\mathrm{M}^{\mathrm{MO}}}^{(\mathrm{p})} \text {, }
\end{aligned}
$$

де $\mathrm{k}_{\mathrm{p} 1}\left(\mathrm{~N}_{\Pi \mathrm{P}}, \mathrm{N}_{\mathrm{C}}\right)$ - коефіцієнт передачі регулятора, значення якого повинно залежати від типу зерна, що транспортується, зокрема від його насипної маси та гідравлічного радіусу;

$\mathrm{T}_{\text {из }}\left(\mathrm{N}_{\mathrm{C}}\right)$ - час изодрома регулятора, пропорційний часу запізнювання в контурі регулювання, який зростає з ростом номера силосу;

$\mathrm{W}_{\mathrm{u}_{1}-\mathrm{M}}^{\mathrm{MO}}(\mathrm{p}), \mathrm{e}^{-\tau_{\mathrm{u}_{1}-\mathrm{M}}^{\mathrm{MO}}}-$ передавальні функції моделі ОК за каналом « $\mathrm{u}_{1}-\mathrm{M»}$ без запізнювання та моделі його запізнювання, час запізнювання $\tau_{\mathrm{u}_{1}-\mathrm{M}}^{\mathrm{MO}}\left(\mathrm{N}_{\mathrm{C}}\right)$;

$$
\mathrm{u}_{12}=\left\{\begin{array}{l}
\operatorname{sign} \Delta \mathrm{f}, \text { при } \mathrm{S}_{\mathrm{M}}^{\Pi \Pi}=0 \wedge \mathrm{k}_{\mathrm{f}} \Delta \mathrm{f}=\mathrm{T}_{\text {и }}-\mathrm{t}^{\prime} \geq 0 \\
0, \text { при } \mathrm{T}_{\text {и }}-\mathrm{t}^{\prime}<0
\end{array},\right.
$$

де $\mathrm{k}_{\mathrm{f}}=\mathrm{T}_{\mathrm{U}} / \Delta \mathrm{f}-$ коефіцієнт перерахунку $\Delta \mathrm{f}$ у $\mathrm{T}_{\mathrm{u}}$;

$\Delta \mathrm{f}(\mathrm{t})=\mathrm{f}_{\text {HOM }}-\mathrm{f}(\mathrm{t})$

t' - час, відлічуваний від моменту початку формування керуючого імпульсу $\mathrm{u}_{12}$;

$$
\begin{aligned}
\mathrm{u}_{2}(\mathrm{t})= & \left\{\begin{array}{l}
\mathrm{W}^{\mathrm{P} 2}(\mathrm{p}) \cdot \Delta \mathrm{f}(\mathrm{t}), \text { при } \mathrm{S}^{\text {дП }}=1 \vee \mathrm{S}_{\mathrm{f}}^{\Pi \Pi}=1 \\
\mathrm{f}_{\text {ном }}=50 \text { гц, при } \mathrm{S}^{\text {ДП }}=0 \wedge \mathrm{S}_{\mathrm{f}}^{\Pi \Pi}=0
\end{array}\right. \\
& \mathrm{W}^{\mathrm{P} 2}(\mathrm{p})=\mathrm{W}_{2}^{\text {ПИ }}(\mathrm{P})=\mathrm{k}_{\mathrm{p} 2}\left(1+1 / \mathrm{T}_{\text {из } 2} \mathrm{p}\right),
\end{aligned}
$$

де $\mathrm{k}_{\mathrm{p}_{2}}, \mathrm{~T}_{\text {из }}$ - коефіцієнт передачі та час ізодрому регулятора;

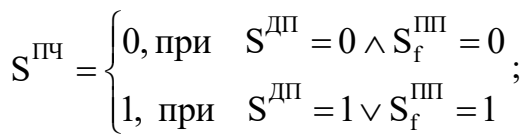

$$
\begin{aligned}
& \mathrm{S}_{\mathrm{f}}^{\Pi \Pi}=\left\{\begin{array}{l}
0, \text { при } \mathrm{W}_{\mathrm{f}}^{\text {ФНЧ }}(\mathrm{p})\left|\left(\mathrm{f}_{\text {ном }}-\mathrm{u}_{2}(\mathrm{t})\right)\right| \leq \Delta \mathrm{f}^{\text {мин }} \\
1, \text { при } \mathrm{W}_{\mathrm{f}}^{\text {ФНЧ }}(\mathrm{p})\left|\left(\mathrm{f}_{\text {ном }}-\mathrm{u}_{2}(\mathrm{t})\right)\right|>\Delta \mathrm{f}^{\text {мин }}
\end{array} ;\right. \\
& \mathrm{S}_{\mathrm{M}}^{\text {ПІІ }}=\left\{\begin{array}{l}
0, \text { при } \mathrm{W}_{\mathrm{M}}^{\text {ФНЧ }}(\mathrm{p})|\Delta \mathrm{M}(\mathrm{t})| \leq \Delta \mathrm{M}^{\text {мин }} \\
1, \text { при } \mathrm{W}_{\mathrm{M}}^{\text {ФНЧ }}(\mathrm{p})|\Delta \mathrm{M}(\mathrm{t})|>\Delta \mathrm{M}^{\text {мин }}
\end{array},\right.
\end{aligned}
$$

де $\mathrm{W}_{\mathrm{f}}^{\Phi н ч}(\mathrm{p})=1 /\left(\mathrm{T}_{\mathrm{cpf}} \mathrm{p}+1\right)^{2}, \mathrm{~W}_{\mathrm{M}}^{\Phi \mathrm{H \Psi}}(\mathrm{p})=1 /\left(\mathrm{T}_{\mathrm{cpM}} \mathrm{p}+1\right)^{2}-$ передавальні функції усереднюючих фільтрів низьких частот;

$\mathrm{T}_{\mathrm{CP}}\left(\mathrm{N}_{\mathrm{C}}\right)$ - постійні часу фільтрів;

$\mathrm{T}_{\mathrm{CP}} \approx 0,25 \Delta \mathrm{t}, \Delta \mathrm{t}-$ необхідний інтервал часу усереднення.

Каскадна структура підсистеми регулювання навантаження ПЕД норії в САК оптимізації заванта-ження ПТЛ

Динамічна точність стабілізації $\mathrm{M}(\mathrm{t})$ на іï заданому значенні $\mathrm{M}^{32 \mathrm{~T}}(\mathrm{t})$ у значній мірі, за інших рівних умов, визначає частоту виникнення $\mathrm{AC} \mathrm{S}^{\text {дП }}=1$, $\mathrm{i}$, отже, досяжну близькість $\mathrm{M}^{32 \mathrm{~T}}(\mathrm{t})$ до $\mathrm{M}^{\mathrm{KP}}$. А це, врешті решт, визначить верхню межу досяжної продуктивності ПТЛ та економічної ефективності її роботи. 
Проблеми забезпечення високої динамічної точності стабілізації М(t) пов'язано з динамічними властивостями ОК. Так, основний контур регулювання $\mathrm{M}(\mathrm{t})$, у якому керуючим впливом $є$ зміна $\mathrm{u}_{1}(\mathrm{t})$, містить у собі дуже велике чисте (транспортне) запізнювання $\tau_{\mathrm{u}_{1}-\mathrm{M}}^{\mathrm{MO}}$ на переміщення зерна. Його значення прямо пропорційне сумарній довжині шляху, на який переміщують зерно конвеєри від завантажувальної засувки до башмака норії. Отже, значення $\tau_{u_{1}-\mathrm{M}}^{\text {мо }} \sigma_{\text {де }}$ змінюватися від місця розташування силосу (його номеру $\mathrm{N}_{\mathrm{C}}$ ) за довжиною розвантажувальних транспортерів.

Наявність запізнювання, що змінюється, вже враховано в базовому алгоритмі керування (1)-(13). Його регулятор $\mathrm{W}_{\mathrm{u}_{1}-\mathrm{M}}^{\mathrm{MO}}(\mathrm{p})$, див. (5)-(7), містить у собі алгоритм прогнозування типу «упереджувач Сміта», а настроювання регулятора, включаючи упереджувач, змінюються зі зміною $\mathrm{N}_{\mathrm{C}}$. Однак такий упереджувач забезпечує прогнозування тільки вільного (власного) руху контуру регулювання, що дає можливість підвищити запас його стійкості, але майже не впливає на амплітуди змушених, тобто прямо викликаних збуреннями, помилок регулювання $\Delta \mathrm{M}(\mathrm{t})[5,6]$. Тому актуально розглянути інші можливості підвищення динамічної точності змушеного руху контуру регулювання «и 1 $M »$.

Ділянка ПТЛ, що включає завантажувальну (регулюючу) засувку, конвеєри та норію, може розглядатися як розподілений у просторі технологічний агрегат. В ньому для виміру доступна не тільки регульована змінна ОК М(t) ступінь навантаження ПЕД норії, але і «внутрішня» («проміжна») змінна - ступінь навантаження ПЕД конвеєра МК(t), на який йде вивантаження зерна із силосу. Важливим фактором тут є те, що зміни проміжної змінної Мк(t), викликані змінами неконтрольованих збурень, сутність яких - зміна характеристик зерна, що призводять до змін його витікання через регулюючу засувку, починають виявлятися раніш на час запізнювання (транспортування зерна конвеєром), чим зміни основної регульованої змінної $\mathrm{M}(\mathrm{t})$, викликані цими ж збуреннями. Таким чином, з'являється можливість підвищення динамічної точності стабілізації $\mathrm{M}(\mathrm{t})$ на основі застосування принципу каскадного регулювання $\mathrm{M}(\mathrm{t}) 3$ проміжною змінною $\mathrm{M}_{\mathrm{K}}(\mathrm{t})$.

Структурная схема такой каскадной САР, без учета особенностей полной САУ с коммутируемой структурой, см. рис. 1, представлена на рис. 2.

Структурну схему такої каскадної САР, без урахування особливостей повної САК зі структурою, що комутується, див. рис. 1, представлено на рис. 2.

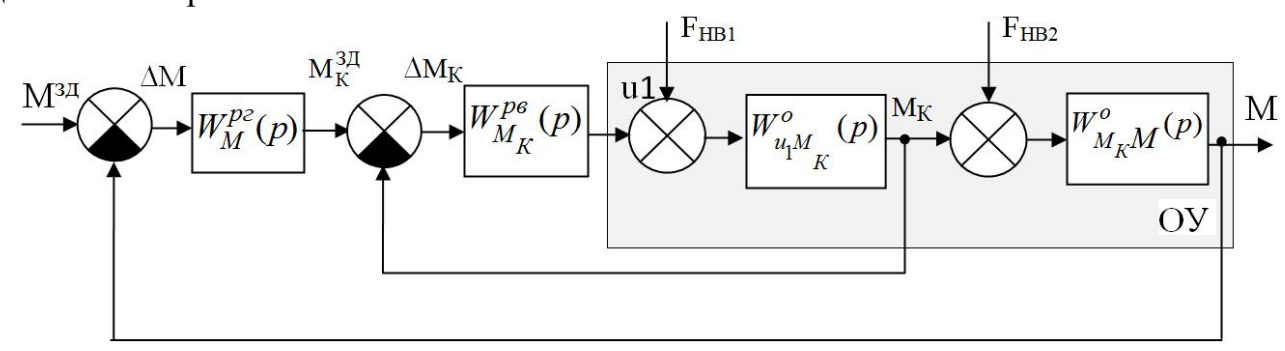

Рис. 2 - Структурна схема каскадної САР навантаження ПЕД норії з використанням навантаження ПЕД конвесра у якості проміжної змінної

Відзначимо, що кожен контур має свій регулятор. Головний зворотний зв'язок замикається через головний регулятор $\mathrm{W}_{\mathrm{M}}^{\mathrm{p}}(\mathrm{p})$, що стабілізує $\mathrm{M}(\mathrm{t})$ на рівні $\mathrm{M}^{3 Д}$. Внутрішній (допоміжний) зворотний зв'язок замикається через допоміжний регулятор $\mathrm{W}_{\mathrm{M}_{\mathrm{K}}}^{\mathrm{pв}}(\mathrm{p})$, що стабілізує $\mathrm{M}_{\mathrm{K}}(\mathrm{t})$ на рівні $\mathrm{M}_{\mathrm{K}}^{\text {зд }}$. При цьому принципово, що керуючий вплив $\mathrm{u}_{1}$, який безпосередньо прикладається до об'єкту, один, і він формується допоміжним регулятором. Керуючий вплив головного регулятора $\mathrm{M}_{\mathrm{K}}^{\text {зд }}$, за своєю суттю, є впливом, що задає, для допоміжного регулятора.

Розглянемо особливості роботи каскадної САР навантаження ПЕД норії у порівнянні з роботою звичайної САР, акцентувавши увагу на можливості підвищення динамічної точності.

Нехай, спочатку, стан обох САР статично сталий, тобто $\Delta \mathrm{M}(\mathrm{t}) \equiv 0$ та $\Delta \mathrm{M}_{\kappa}(\mathrm{t}) \equiv 0 \forall \mathrm{t}<0$. Потім, у момент часу $\mathrm{t}=0$, подіяло збурення $\mathrm{F}_{\mathrm{HB} 1}$.

$\mathrm{У}$ звичайній CAP регулятор $\mathrm{W}_{\mathrm{M}}^{\mathrm{p}}(\mathrm{p})$ починав би змінювати свій керуючий вплив $\mathrm{u}_{1}(\mathrm{t})$ та компенсувати наслідки впливу $\mathrm{F}_{\mathrm{HB} 1}$, тільки тоді, коли почалася б зміна вихідної змінної $\mathrm{M}(\mathrm{t})$, тому що $\mathrm{M}_{\kappa}(\mathrm{t})$ такої САР не вимірюється. При цьому керуючий вплив починав би повертати $\mathrm{M}(\mathrm{t})$ до $\mathrm{M}_{\mathrm{K}}^{3 д}$ тільки через час, більший, ніж $2 \tau_{\mathrm{u}_{1}-\mathrm{M}}^{\mathrm{MO}}$. Така ситуація призводить до великих динамічних помилок $\Delta \mathrm{M}(\mathrm{t})$, причому, чим більше $\tau_{\mathrm{u}_{1}-\mathrm{M}}^{\mathrm{MO}}$, за інших рівних умов, тим більше ці помилки.

У каскадній системі, оскільки $\mathrm{M}_{\kappa}(\mathrm{t})$ вимірюється, дія $\mathrm{F}_{\mathrm{HB} 1}$ початково проявиться у зміні $\mathrm{M}_{\kappa}(\mathrm{t})$. Запізнювання у 1-ій 
частині каналу регулювання $\mathrm{M}$, тобто в каналі « $\mathrm{u}_{1}-\mathrm{M}_{\mathrm{K}}$, близько до нуля. Тому допоміжний регулятор $\mathrm{W}_{\mathrm{M}}^{\mathrm{p}}(\mathrm{p})$ почне відпрацьовувати виниклу помилку регулювання $\Delta \mathrm{M}_{\kappa}(\mathrm{t})$ раніш i тому зможе забезпечити більш високу динамічну точність стабілізації $\mathrm{M}_{\mathrm{K}}(\mathrm{t})$, а за рахунок цього знизить вплив $\mathrm{F}_{1}$ на $\mathrm{M}(\mathrm{t})$.

Збурення $\mathrm{F}_{\mathrm{HB} 2}$ не впливають на $\mathrm{M}_{\kappa}$. Їхня сутність - вплив характеристик зерна на критичний ступінь заповнення ковшів норії i, як наслідок - на рівень зерна в іiї башмаку i, отже, на M(t). Це одночасно свідчить, що між $\mathrm{M}_{\mathrm{K}}$ та $\mathrm{M}$ немає однозначної відповідності, тобто неможливо за відомим $\mathrm{M}^{3 д}$ заздалегідь розрахувати відповідне йому задане

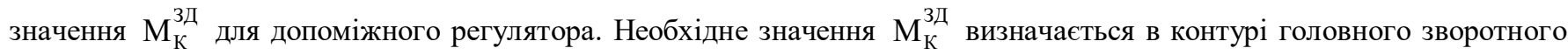
зв'язку, коли головний регулятор $\mathrm{W}_{\mathrm{M}}^{\mathrm{p}}(\mathrm{p})$ прагне забезпечити $\Delta \mathrm{M}(\mathrm{t})=0$. Якщо $\Delta \mathrm{M}(\mathrm{t}) \equiv 0$ це буде свідчити, що необхідне $\mathrm{M}_{\kappa}=\mathrm{M}_{\mathrm{K}}^{\text {зд }}$ знайдене.

Таким чином, у внутрішньому контурі, допоміжним регулятором забезпечується ефективна стабілізація Мк на рівні $\mathrm{M}_{\mathrm{K}}^{3 Д}$, а в контурі головного зворотного зв'язку головним регулятором визначається те задане значення $\mathrm{M}_{\mathrm{K}}^{3 Д}$, яке повинне підтримуватися допоміжним регулятором, при якому досягається $\mathrm{M}=\mathrm{M}^{3 Д}$.

Результати моделювання та їхній аналіз

На рис. 3 та 4 наведено фрагменти результатів імітаційного моделювання САК зі структурою, що комутується. Умови моделювання: норія та конвеєри, що подають на неї зерно - номінальна продуктивність 100 т/год. (3 пшениці); підсилосна засувка - з регульованим прохідним вікном $0,3 * 0,3$ метри з максимальною продуктивністю до 250 т/год.; час транспортування зерна від засувки до норії - 30 секунд; потужність ПЕД норії - 18,5 квт; оцінка ступеня завантаження норії - за відносним моментом, що розраховується, на валу ПЕД [7].
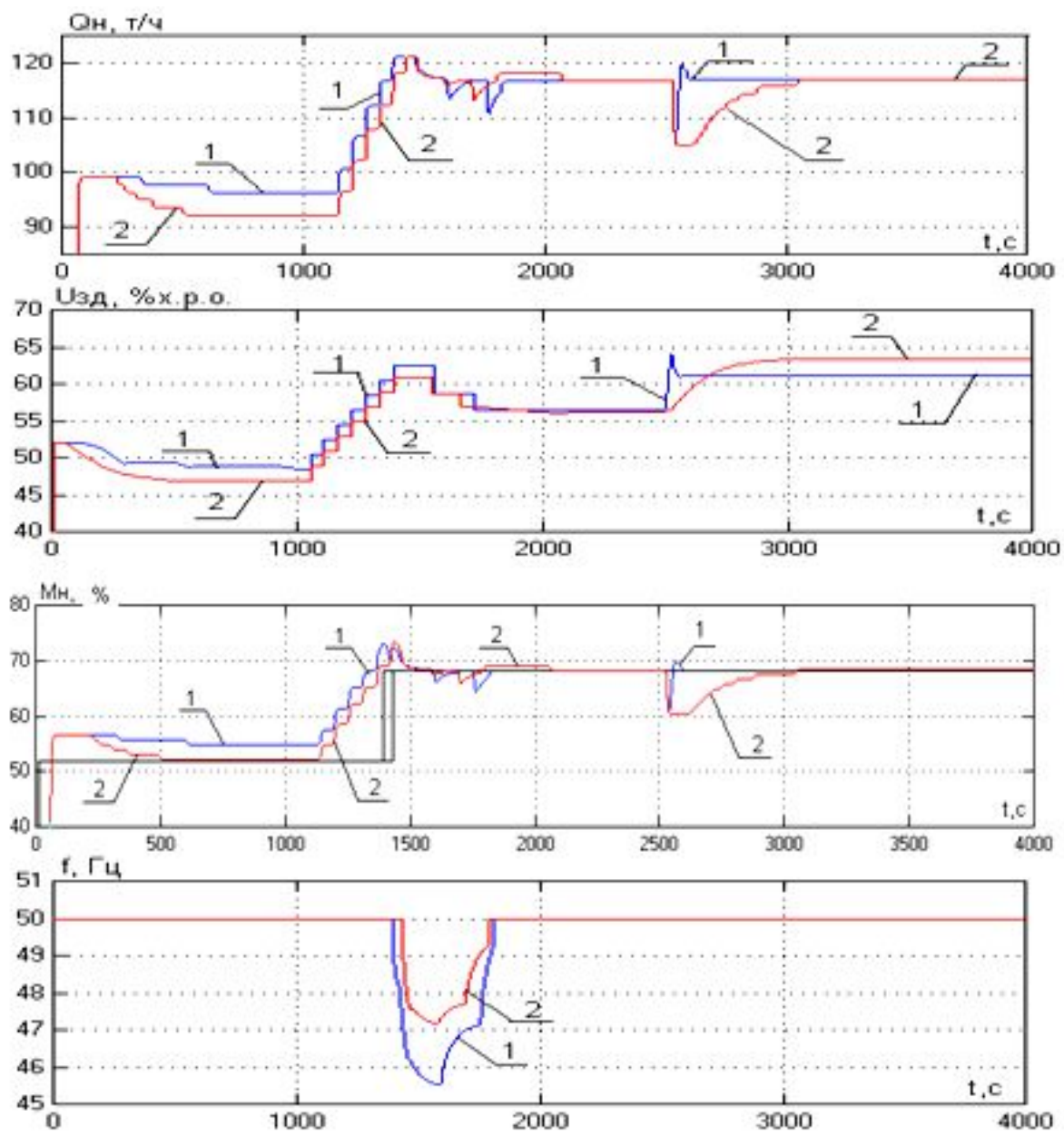

Рис. 3 - Процеси керування в САК зі структурою, що комутується, объектом 3 обмеженнями типу «аварійна ситуація, яку викликано підпором зерна в норії» (1 - САК з каскадним контуром стабілізації $\mathrm{M}_{\mathrm{H}} ; 2$ - базова САК) 

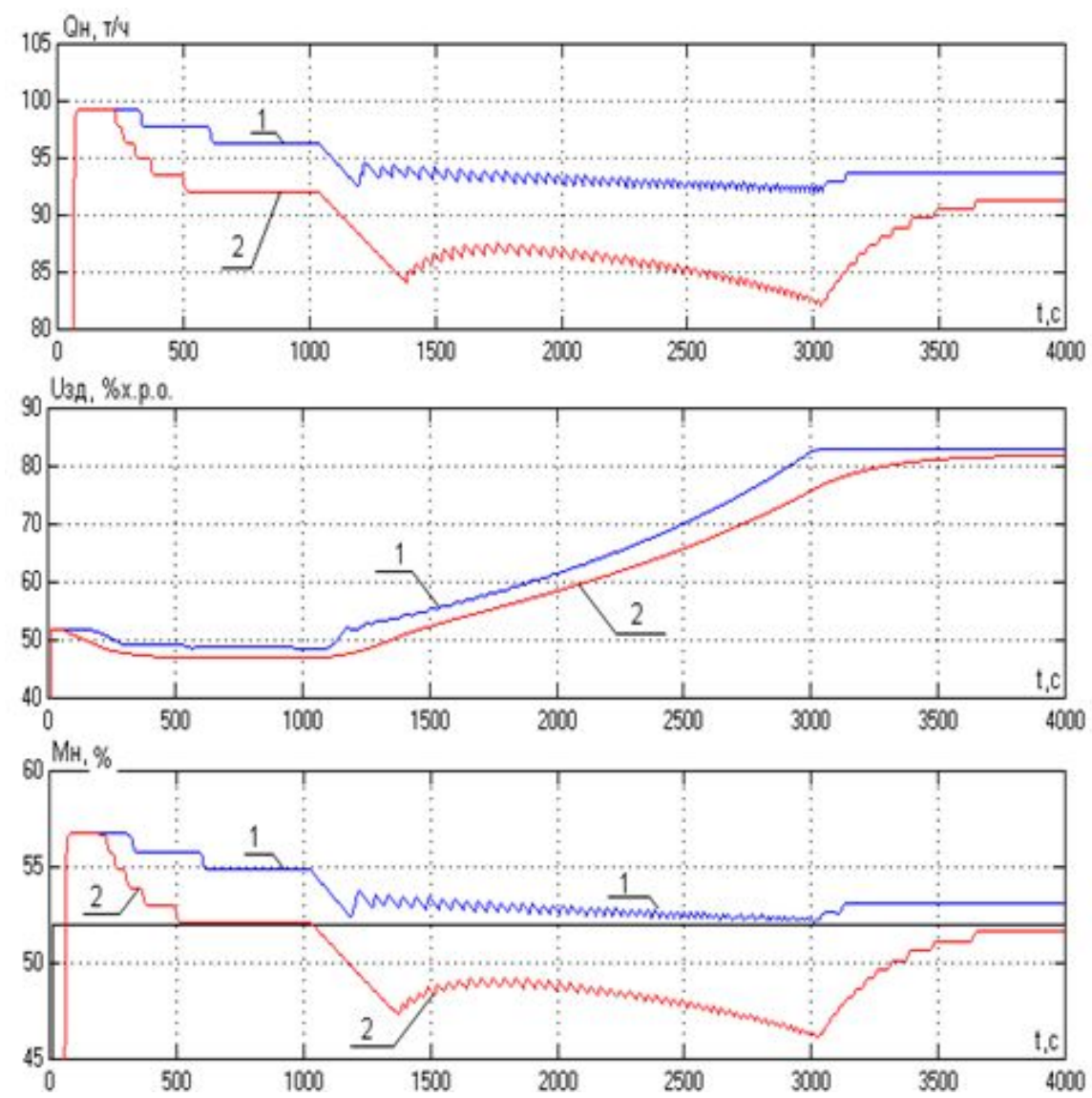

Рис. 4 - Процеси керування в САК зі структурою, що комутується (за рис. 3) (1 - САК 3 каскадним контуром стабілізації Мн; 2 - базова САК)

\section{Висновки}

1. Формалізоване (математичне) надання алгоритму керування САК зі структурою, що комутирується, та реалізує функцію оптимізації завантаження ПТЛ елеваторів зерном, дозволяє формалізувати розробку ПЗ таких САК для ПТЛ елеваторів практично будь-яких конфігурацій та параметрів.

2. Резерви підвищення продуктивності та енергоефективності ПТЛ за рахунок підвищення завантаження ПТЛ, i, одночасно, при збереженні імовірності виникнення АС, викликаної завалом зерном башмака норії, пов'язані 3 можливістю підвищення точності регулювання (стабілізації на оптимальному значенні) відносного моменту опору на валу ПЕД норії. Перспективним напрямком у такому удосконаленні є застосування в контурі регулювання відносного моменту ПЕД норії каскадної структури. Проміжною змінною в такій структурі підсистеми регулювання доцільно взяти відносний момент ПЕД підсилосного конвеєра.

3. Складності при реалізації каскадної структури за п.2 пов'язані з істотною зміною властивостей підсилосного конвеєра як ОК при зміні номеру силосу, з якого здійснюється розвантаження зерна на конвеєр. Вони полягають у необхідності установки настройювальних параметрів «допоміжних» регуляторів та початкових заданих значень їхніх регульованих змінних, що відповідають номеру силоса. Крім того, очевидно, що обчислення відносного моменту ПЕД підсилосного конвеєру при його завантаженні із силосів, близьких до його «хвосту», буде мати більш низьку точність через співвідношення, що зменшується, корисного навантаження ПЕД до його навантаження холостого ходу.

\section{Література}

[1] Хобин В.А. Математическая модель нории как объекта управления с изменяющимися свойствами. Моделирование процесса заполнения ковшей / В. А. Хобин, И. Н. Кирьязов // Наук. пр. ОНАХТ. - Одеса: 2012. - Вип. 42. - Т. 1. - С. 358-368.

[2] Хобин В.А. Концепция эффективного управления производительностью поточно-траспортных линий при перегрузке зерна / В. А. Хобин, С. В. Шестопалов // Хранение и переработка зерна. - Днепропетровск, 2011. № 10 (148). - С. 26-29.

[3] Пат. на винахід 95887 Україна, МПК (2011.01), B65G 17/00, B65G 47/46 (2006.01), B65G 65/42 (2006.01), G01G 11/12 (2006.01). Спосіб автоматичного управління завантаженням потоково-транспортної лінії сипких матеріалів / Аннаєв Б. С., Герасимов В. В., Хобін В. А., Кір’язов І. М., Шестопалов С. В. і ін.; власник ТОВ «С- 
Інжинірінг». - № а201015861; заявл. 29.12.10; опубл. 12.09.11, Бюл. № 17. - 24 с.

[4] Шестопалов С.В. Оптимизация загрузки ПТЛ элеваторов зерном на основе САУ с коммутируемой структурой / С. В. Шестопалов, В. А. Хобин // Автоматизация технологических и бизнес-процессов. - Одесса, 2015. - № 3. T. 7. - C.17-26.

[5] Гурецкий Х. Анализ и синтез систем управления с запаздыванием [пер. с польского] / Х. Гурецкий // М. : Машиностроение, 1974. - 328 с.

[6] Хобин В.А. Системы гарантирующего управления технологическими агрегатами: основы теории, практика применения / В. А. Хобин // Монография: Одесса: «ТЭС», 2008. - 304 с.

[7] Пат. на винахід 99525 Україна, МПК (2011.01), B65G 17/00, G01R 29/00. Спосіб контролю ступеня завантаження конвеєра / Аннаєв Б. С., Герасимов В. В., Хобін В. А., Кір'язов І. М. і ін.; заявник та патентовласник ТОВ «С-Інжинірінг». - № а201014455; заявл. 03.12.10; опубл. 25.05.12, Бюл. № 10. - 14 с.

References

[1] V.A. Khobin Matematicheskaya model' norii kak ob"yekta upravleniya s izmenyayushchimisya svoystvami. Modelirovaniye protsessa zapolneniya kovshey. Odesa: Nauk. pr. ONAFT, vol. 1, issue 42, pp. 358-368, 2012.

[2] V.A. Khobin Kontseptsiya effektivnogo upravleniya proizvoditel'nost'yu potochno-trasportnykh liniy pri peregruzke zerna. Dnepropetrovsk: Khraneniye i pererabotka zerna, № 10 (148), pp. 26-29, 2011.

[3] B. S. Annayev, V.V. Herasymov, V.A. Khobin, I.M. Kiryazov, S.V. Shestopalov Patent na vynakhid №95887 Ukraine, MPK (2011.01), B65G 17/00, B65G 47/46 (2006.01), B65G 65/42 (2006.01), G01G 11/12 (2006.01). Sposib avtomatychnoho upravlinnya zavantazhennyam potokovo-transportnoyi liniyi sypkykh materialiv. Owner of "SEngineering" Ltd. № a201015861; September 12, 2011.

[4] S.V. Shestopalov V. A. Khobyn Optymyzatsyya zahruzky PTL élevatorov zernom na osnove SAU s kommutyruemoy strukturoy. Odessa: Automation of technological and business processes, vol. 7, issue 3, pp.17-26, 2015.

[5] K.H. Guretskiy Analiz i sintez sistem upravleniya s zapazdyvaniyem [trans. from Polish] M. : Mashinostroyeniye, 328 p., 1974.

[6] V.A. Khobin Systems guaranteeing control of technological units: the fundamentals of the theory, application practice Monograph. Odessa: «TES», 304 p., 2008.

[7] B. S. Annayev, V.V. Herasymov, V.A. Khobin, I.M. Kiryazov, S.V. Shestopalov Patent na vynakhid №99525 Ukraine, MPK (2011.01), B65G 17/00, G01R 29/00. Sposib kontrolyu stupenya zavantazhennya konveyera. Owner of "SEngineering" Ltd. № a201014455; May 25, 2012.

\title{
VOCATIONAL TRAINING OF COMPETITIVE ENGINEERS THROUGH THE USE OF COMPUTER TECHNOLOGIES
}

\author{
Yu. G. Loboda ${ }^{1}$, E.U. Orlova ${ }^{2}$, V.E. Volkov ${ }^{3}$ \\ 1,2,3 Odessa National Academy of Food Technologies, Odessa, Ukraine \\ ORCID: ${ }^{1} 0000-0003-4857-7389,{ }^{2} 0000-0003-1865-4742,{ }^{3} 0000-0002-3990-8126$ \\ E-mail: 1jul.loboda@gmail.com, ${ }^{2}$ olenaorlova69@gmail.com, ${ }^{3}$ viktor@te.net.ua
}

Copyright (C) 2017 by author and the journal "Automation technological and business - processes". This work is licensed under the Creative Commons Attribution International License (CC BY). http://creativecommons.org/licenses/by/4.0/

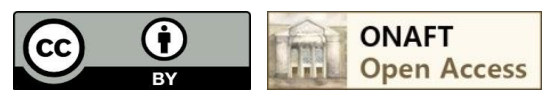

Abstract: The article is concerned with the increasing importance of computer technologies and the need to educate an engineer at the level of modern advances in science and technology. New methods and technologies of learning based on 